\title{
Activating ALK Gene Mutation Negative
}

National Cancer Institute

\section{Source}

National Cancer Institute. Activating ALK Gene Mutation Negative. NCI Thesaurus. Code C158068.

A genetic finding indicating that mutations in the ALK gene which encode constitutively active forms of the ALK tyrosine kinase receptor protein are not present in a sample. 